\title{
Predicting customer's intentions to use internet banking: the role of technology acceptance model (TAM) in e-banking
}

\author{
Samar Rahi ${ }^{\text {a*}}$, Mazuri Abd. Ghani ${ }^{\mathrm{b}}$ and Feras MI Alnaser ${ }^{\mathrm{a}}$
}

${ }^{a}$ PhD scholar, University Sultan Zainal Abidin, Terengganu, Malaysia

${ }^{b}$ Senior Lecturer, University Sultan Zainal Abidin, Terengganu, Malaysia

CH R O N I C L E A B T T A C T

Article history:

Received: February 1, 2017

Received in revised format: July

6, 2017

Accepted: August 6, 2017

Available online:

August 9, 2017

Keywords:

Internet banking

Perceived usefulness

Perceived ease of use

Attitude

Intention

Technology acceptance model

(TAM)

\begin{abstract}
Information and communication technology (ICT) developments and trends in recent years have had great impacts on banking sector worldwide. Therefore, the disruptive innovative technology has accelerated changes in the way of banking business. The purpose of this paper is to explore the factors that influence on Pakistani customer's intentions to adopt internet banking. The sample used in this empirical study includes 265 responses of internet banking users collected through structured questionnaire. For statistical analysis, structural equation model (SEM) approach was used. The present study suggests that internet banking use increases as long as customer perceives it as useful tool. Findings confirmed that perceived usefulness, perceived ease of use and attitude were the key constructs for promoting internet banking usage in Pakistan. Furthermore, the importance performance matrix analysis has shown that attitude was the most important factor. Thus, banks can focus on cultivation of positive attitudinal beliefs about internet banking among prospect customers.
\end{abstract}

\section{Introduction}

Since 1995, Internet banking has allowed consumers to utilize the internet as a platform to interact with their banks (O'Reilly \& Finnegan, 2003). The use of disruptive innovative technologies has accelerated changes in the way banking business is conducted and consumers are swept with such changes. Thus, in today's competitive market, it is necessary to provide fast services for customers. Internet banking allows customers to use their banks' websites to perform common banking transactions such as paying bills, transferring funds inquiring about account balances, etc. (Lee, 2009). According to Rahi et al.(2017), internet banking involves a process where users get access to their own bank accounts and perform transaction directly such as payment of utility bills, transfer of funds, etc. Furthermore, Martins et al. (2014) explained that internet banking is the delivery of banking services through an open access computer network (the Internet) to offer a wider range of potential benefits to financial institutions due to more accessible and user friendly use of the technology.

\footnotetext{
* Corresponding author.

E-mail address: sr_adroit@yahoo.com (S. Rahi) 
Internet banking provides a very convenient and effective method of managing personal finances because it is flexible (Lee, 2009). Additionally, the convenience offered by internet banking is making it popular, which, in turn, encourages banks to provide a safe and efficient banking system for their customers (Lee, 2009). The use of internet is not limited to banking sector. It could be used for noncommercial activities like paying the tax or entertainment. According to Rahi (2015) e-commerce is defined as an applications that facilitate two or more than two parties for the purpose of business exchanges. Internet technology plays essential role in banking system and performs different types of transactions with minimum risk. Soon people will give priority to internet banking for all types of transactions (Rahi, 2016). Furthermore, the technology is playing a key role in every type of business and it is impossible to get competitive advantages without having the access to technology (Zhuang \& Lederer, 2004). Jayawardhena and Foley (2000) argue that internet banking will change the way of services and interaction between mangers and customers. Although several studies have examined the banking industry, however most of these focused on traditional banking services such as evaluation the quality, marketing and development of new services (Rahi, 2015; Rahi, 2016a; Rahi, 2016b; Rahi \& Ghani, 2016a; Rahi \& Ghani, 2016b; Suleiman Awwad \& Mohammad Agti, 2011). Several studies have focused on positive aspects of internet banking for instance related benefits, trust worthiness and innovation (Han \& Baek, 2004). One study conducted by Chong et al. (2010) empirically examined that the factors such as perceived ease of use, trust and government support influence on adoption of internet banking. In line with Chong et al. (2010) the present study scrutinized the technology acceptance model to investigate the internet banking adoption issues in Pakistan.

\section{Literature Review}

\subsection{Theoretical background}

Earlier studies related to adoption of technology were conducted which sought to understand how different factors affect individuals' technology adoption behavior. During the last two decades, technology acceptance model has been extensively evolved in technology adoption studies. Technology acceptance model has gone through three phases of development: adoption, validation and extension. At adoption level TAM was tested with several information system applications; for instance communication technologies and internet related applications. In validation phase, it was tested to prove causal links among TAM constructs whilst extension phase presents the extension of the two main constructs perceived usefulness and perceived ease of use (Han, 2003). In views of Wixom and Todd (2005), the TAM model includes three types of extension approaches. The first approach suggests an extension with related factors involved in models; for instance subjective norms or perceived behavioral control. The second approach recommends involving alternative beliefs for instance compatibility, visibility or demonstrability whilst, the third approach is directed to extension with external variables.

\subsection{Behavioral Intention}

Behavioral intention has been observed as an indicator of system success (Venkatesh et al., 2003). According to Zeithaml et al. (1996) behavioral intention is relevant to customers' decision and their desires to stay or switch from company services. Zhang and Prybutok (2005) suggested that customer experience is more related to behavioral intention. It is said that the more positive customer's experience, the more likely that the customers will show the intention to buy or use the services.

\subsection{Perceived Usefulness}

According to Wang et al. (2003) perceived usefulness is defined as the extent to which a person believes that using a particular system will enhance his or her job performance. In internet banking context, perceived usefulness could be in transactions such as request for cheque/demand draft, sending monthly e-statements, online payments, that improves performance, save time and increase effectiveness of the 
services (Kesharwani \& Singh Bisht, 2012). Moreover, these benefits also are expected to be further enhancing over a period of time through technological advancement or break through. The more useful the system is seen, the more likely intention towards the use of internet banking (Lee, 2009). The literature shows that perceived usefulness has significant effect on behavioral intention concerning technology use and has been tested and validated by different researchers (Kesharwani \& Singh Bisht, 2012; Lee, 2009; Venkatesh \& Davis, 2000). Thus, the following hypothesis is formulated:

H1: Perceived Usefulness positively influences on attitude.

\subsection{Perceived Ease of Use}

According to Venkatesh and Davis (2000) technology will be more useful if it is easier to use. If an internet service is found to be very difficult to use, customers will choose another way to make transaction (Venkatesh \& Davis, 2000). The more difficult the system is to use, the less likely the customer uses. Venkatesh and Davis (2000) revealed several determinants of perceived ease of use by integrating computer self-efficacy and facilitation condition into technology acceptance model. In internet banking context researchers show that perceived ease of use had a positive and significant influence on perceived usefulness (Bashir \& Madhavaiah, 2015; Rahi, 2016a,b; Wang et al., 2003). Thus, following hypothesis is formulated;

H2: Perceived Ease of Use influences positively on perceived usefulness.

H3: Perceived Ease of Use influences positively on attitude.

\subsection{Attitude}

In previous studies, Attitude is defined as " the degree to which a person has a favorable evaluation or appraisal of the behaviors in question" (Ajzen \& Fishbein, 1980). Several studies have confirmed that in technology field attitude has a significant influence on behavioral intention (Al-Ajam \& Md Nor, 2015; Kesharwani \& Singh Bisht, 2012). In technology related studies, Wu (2006) found significant relationship between attitude and intention in online bookstore. The effect of attitude on intention has been also supported in internet banking domain (AbuShanab et al., 2010; Al-Ajam \& Md Nor, 2015; Rahi, 2016a,b). Thus, it can be concluded that attitude played a significant role on individual intention for adoption of internet banking. Therefore, the following hypothesis is generated;

H4: Attitude influences positively on intention to use internet banking.

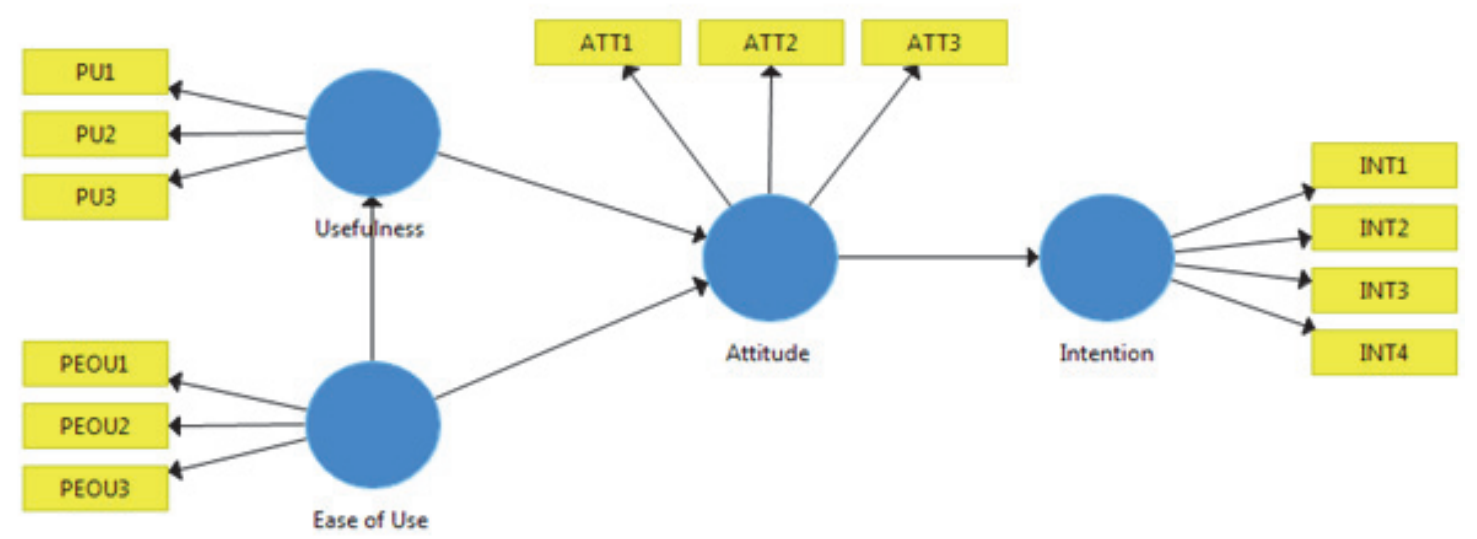

Fig. 1. Theoretical Framework 


\section{Methods}

\subsection{Survey Design and Sampling}

This study is conducted under positivist paradigm. Becker et al. (2012) postulated that positivists believe in employing quantitative approaches for data analysis and support objectivity to define their ontological statements. Thus quantitative approach was used to verify the influence of technology acceptance model on intention to adopt internet banking. A questionnaire was developed for measuring the respondent's observation. Survey was directed towards customers of commercial Banks in Lahore city of Pakistan. The data was collected between the months of October 2015 and November 2015 from Lahore city of Punjab, Pakistan. Convenience sampling method was used in this study. Convenience sampling is defined as a process of data collection from population that is close at hand and easily accessible to researcher (Rahi, 2017). Hair (2003) illustrated that convenience sampling allows researcher to complete interviews or get responses in a cost effective way. Comrey and Lee (1992) stated that sample size of 50 is very poor, while 100 is poor, 200 is reasonable, 300 is good, 500 is very good and 1000 is brilliant for structural equation modeling. Thus, for this study the required sample size was 265. However, researcher set out to collect data which was slightly larger than the required number. A set of 400 structured questionnaires were distributed out of 265 useable response received from internet banking users.

\subsection{Instrument Development}

The survey instrument was consisted on two parts. First part asked about demographic characteristics like region, age, gender, qualification while, second part included four latent constructs namely; perceived usefulness, perceived ease of use, attitude and intention to adopt internet banking. All the constructs items were adopted from previous research works. Items of intention was adopted from Rahi et al. (2017) while perceived usefulness, perceived ease of use and attitude were adapted from Davis (1989). The items anchored on a 7-point Likert scale (1= strongly disagree to 7 strongly agree)

\subsection{Respondent's Profile}

The demographics of 265 respondents are tabulated in Table 1. Males were (53.2\%) slightly more than females $(46.8 \%)$. The age of the respondents $26.8 \%$ was for less than 25 years old, $35.8 \%$ that counts at age between 26 to 35 years, $26.7 \%$ for 36 to 45 years and about $9.4 \%$ respondents were above 46 . Overall a good mixture of age was directed in this study of internet banking adoption. Data was further analyzed with demographic characteristics such as education. Education of the respondents were asked where only $1.9 \%$ respondents were considered below high school education, $4.2 \%$ from those who attended high school, $8.3 \%$ respondents who attended college, the maximum share was graduate respondents with $56.2 \%$ and finally $29.4 \%$ respondents were post graduated and participated in internet banking adoption study.

\section{Table 1}

Demographic profile of the respondents

\begin{tabular}{|c|c|c|}
\hline Demographic Characteristics & Frequency & Percentage (\%) \\
\hline \multicolumn{3}{|c|}{ Gender } \\
\hline Male & 141 & 53.2 \\
\hline Female & 124 & 46.8 \\
\hline \multicolumn{3}{|c|}{ Age } \\
\hline Less than 25 years & 71 & 26.8 \\
\hline $26-35$ years & 95 & 35.8 \\
\hline $36-45$ years & 74 & 27.7 \\
\hline 46 years and above & 25 & 9.4 \\
\hline \multicolumn{3}{|c|}{ Education } \\
\hline Below high School & 5 & 1.9 \\
\hline Attended High School & 11 & 4.2 \\
\hline Attended College & 22 & 8.3 \\
\hline Graduate & 149 & 56.2 \\
\hline Post Graduate & 78 & 29.4 \\
\hline
\end{tabular}




\section{Data Analysis}

To analyze the research model Partial Least Square (PLS) analysis technique was employed by using the SmartPLS3.0 software (Ringle et al., 2015). Following two-stage analytical procedure, researchers tested the measurement model (validity and reliability of the measures) and structural model (Hypothesis testing) recommended by Hair Jr et al. (2014).

\subsection{Measurement Model}

Prior to structural modelling assessment, the study has to evaluate the measurement model of latent construct for their dimensionality, validity, and reliability by going through the process named as confirmatory factor analysis (CFA). As the study is quantitative in nature, usually Cronbach's $(\alpha)$ is recommended to ensure reliability. Therefore, Composite Reliability (CR) is also preferred (Henseler et al., 2009). Two types of validity approached: Convergent and discriminate validity.

\subsection{Convergent Validity}

Convergent validity of measurement model is usually ascertained by examining the factor loading, average variance extracted and compost reliability (Hair et al., 2010). Fig. 2 depicted the result where, factor loading values was supported by Chin (1998) by recommended threshold level of 0.6. All the values were above than 0.6 that indicates the convergent validity.

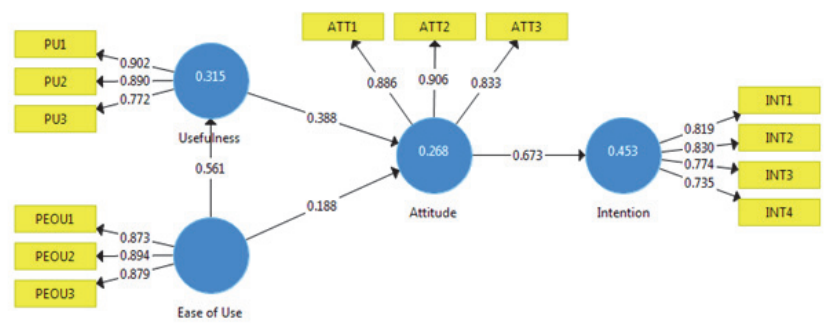

Fig. 2. Measurement Model

The convergent validity was also confirmed through estimation of average variance extracted (AVE) by recommended values of Fornell and Larcker (1981) as it must be greater than 0.5 . The average variance extracted that reflects the overall amount of variance in the indicators was accounted for latent construct.

\section{Table 2}

Results of Measurement Model

\begin{tabular}{|c|c|c|c|c|}
\hline Constructs & Loading & $(\boldsymbol{\alpha})$ & $\mathbf{C R}$ & AVE \\
\hline Perceived Usefulness & $\mathbf{P U}$ & 0.816 & 0.892 & 0.734 \\
\hline I think internet banking makes it easier for me to do my banking activities. & 0.902 & & & \\
\hline I think internet banking enables me to complete my banking activities more quickly. & 0.89 & & & \\
\hline I think internet banking allows me to manage my banking activities more efficiently. & 0.772 & & & \\
\hline Perceived Ease of Use & PEOU & 0.857 & 0.913 & 0.778 \\
\hline I think it is easy to learn how to use internet banking. & 0.873 & & & \\
\hline I believe that it is easy to get internet banking to do what I want it to do. & 0.894 & & & \\
\hline I think it is easy to remember how to use internet banking. & 0.879 & & & \\
\hline Attitude & ATT & 0.847 & 0.908 & 0.766 \\
\hline In my opinion, it is desirable to use the banks Website. & 0.886 & & & \\
\hline Using bank's Website is a pleasant experience. & 0.906 & & & \\
\hline Using bank's Website is a wise idea. & 0.833 & & & \\
\hline Intention to adopt internet Banking & INT & 0.803 & 0.869 & 0.625 \\
\hline I expect to use internet banking in the future. & 0.819 & & & \\
\hline I plan to use internet banking in the next months. & 0.83 & & & \\
\hline I intend to consult the balance of my account on the platform of Internet banking. & 0.774 & & & \\
\hline I intend to perform a transfer on the platform of Internet banking. & 0.735 & & & \\
\hline
\end{tabular}


Further to this measurement, model needs to assess the composite reliability. Table 2 depicts composite reliability (CR) degree where the construct indicator represents the latent construct, values exceeded 0.7 recommended by Hair et al. (2010).

\subsection{Discriminate Validity}

The discriminate validity of the measures was examined by Fornell and Larcker (1981). Discriminate validity is the degree where items are differentiated among constructs and measures distinct concepts (Fornell \& Larcker, 1981). It is measured by examining the correlation between the measures of the potential overlapping constructs (Fornell \& Larcker, 1981). According to Compeau et al. (1999) the average variance shared between each construct and its measure should be greater than the variance shared between the constructs and other constructs. Table 3 shows that the square root of the AVE as shown in bold values on the diagonals were greater than the corresponding row and column values that indicates the measures were discriminate.

Table 3

Discriminate validity of Measurement Model

\begin{tabular}{ccccc}
\hline Constructs & Attitude & Ease of Use & Intention & Usefulness \\
\hline Attitude & 0.875 & & & \\
Ease of Use & 0.406 & 0.882 & 0.79 & 0.857 \\
\hline Intention & 0.673 & 0.463 & 0.542 & \\
\hline Usefulness & 0.494 & 0.561 & & \\
\hline
\end{tabular}

Note: Bold values indicate the square root of AVE of each construct

Discriminate validity can be measured by examining the cross loading of the indicators (Hair Jr et al., 2016). It can be performed by comparing an indicator's outer loadings on the associated constructs and it should be greater than all of its loading on the other constructs (Ngah et al., 2015). Table 4 depicts that all the items measuring a particular constructs loaded higher on that construct and loaded lower on the other constructs that confirms the discriminate validity of the constructs.

Table 4

Loading and Cross Loadings

\begin{tabular}{ccccc}
\hline Items & Attitude & Intention & Ease of Use & Usefulness \\
\hline ATT1 & $\mathbf{0 . 8 8 6}$ & 0.568 & 0.325 & 0.444 \\
ATT2 & $\mathbf{0 . 9 0 6}$ & 0.614 & 0.391 & 0.476 \\
ATT3 & $\mathbf{0 . 8 3 3}$ & 0.585 & 0.348 & 0.373 \\
INT1 & 0.618 & $\mathbf{0 . 8 1 9}$ & 0.295 & 0.393 \\
INT2 & 0.585 & $\mathbf{0 . 8 3 0}$ & 0.413 & 0.407 \\
INT3 & 0.454 & $\mathbf{0 . 7 7 4}$ & 0.359 & 0.468 \\
INT4 & 0.435 & $\mathbf{0 . 7 3 5}$ & 0.422 & 0.471 \\
PEOU1 & 0.365 & 0.387 & $\mathbf{0 . 8 7 3}$ & 0.51 \\
PEOU2 & 0.302 & 0.393 & $\mathbf{0 . 8 9 4}$ & 0.504 \\
PEOU3 & 0.403 & 0.443 & $\mathbf{0 . 8 7 9}$ & $\mathbf{0 . 9 0 2}$ \\
PU1 & 0.442 & 0.486 & 0.536 & $\mathbf{0 . 8 9 0}$ \\
PU2 & 0.407 & 0.496 & 0.475 & $\mathbf{0 . 7 7 2}$ \\
\hline PU3 & 0.421 & 0.406 & 0.425 & \\
\hline
\end{tabular}

\subsubsection{Heterotrait-Monotrait Ratio (HTMT)}

There is another approach to assess the discriminant validity suggested by Henseler et al. (2015) through multitrait and multimethod matrix, namely the Heterotrait-Monotrait Ratio (HTMT). There are two ways of using the HTMT approach to assess the discriminant validity. At first, when using it as a criterion, if HTMT value is greater than 0.85 , then there is a problem with discriminant validity. Secondly, by using statistical test for HTMT inference when the confidence interval of HTMT values for the structural paths contains the value if 1 , it indicates a lack of discriminant validity. If the value of 1 falls outside the interval's range, it suggests that the constructs are empirically distinct. HTMT results can be seen in following Table 5 . 
Table 5

Heterotrait-Monotrait Ratio (HTMT)

\begin{tabular}{|c|c|c|c|c|}
\hline Constructs & Attitude & Ease of Use & Intention & Usefulness \\
\hline Attitude & -------- & & & \\
\hline Ease of Use & $\begin{array}{c}0.474 \\
\text { CI.90 } \\
(0.361,0.575)\end{array}$ & & & \\
\hline Intention & $\begin{array}{c}0.800 \\
\text { CI.90 } \\
(0.703,0.879)\end{array}$ & $\begin{array}{c}0.564 \\
\text { CI.90 } \\
(0.454,0.654)\end{array}$ & & \\
\hline Usefulness & $\begin{array}{c}0.594 \\
\text { CI.90 } \\
(0.502,0.676)\end{array}$ & $\begin{array}{c}0.669 \\
\text { CI.90 } \\
(0.582,0.747)\end{array}$ & $\begin{array}{c}0.679 \\
\text { CI.90 } \\
(0.595,0.762)\end{array}$ & ---------- \\
\hline
\end{tabular}

Note: Heterotrait-Monotrait Ratio (HTMT) discriminate at (HTMT $<0.9 /$ HTMT $<0.85$ )

Based on the results of Table 5, all HTMT values are lower than the required threshold value of HTMT.85 by Kline (2011) and HTMT of .90 by Gold and Arvind Malhotra (2001), indicating that discriminate validity is valid for this study. Furthermore, the result shows that neither lower nor upper confidence interval (CI) includes a value of 1 . To sum up, both convergent and discriminant validity of the measure were developed.

\subsection{Structural Model Evaluation}

Measurement model was achieved after conducting validity and reliability analysis. Moving further with Smart PLS3.0 software (Ringle et al., 2015) structural equation model (SEM) was performed to assess the strength of the of the proposed model for this study. In order to assess the structural model lateral collinearity test (VIF), $R^{2}$ values and corresponding t-values were evaluated as suggested by Hair Jr et al. (2016). The proposed hypothesis were tested by running a bootstrapping procedure with a resample of 5000, as suggested by Hair Jr et al. (2014).

\subsection{Lateral Collinearity Assessment}

At first stage of structural equation model, lateral collinearity was assessed with collinearity statistics VIF. According to Kock and Lynn (2012) although vertical collinearity are met, lateral collinearity (predictor- criterion collinearity) may sometimes be misleading the findings. This type of collinearity is occurred when two variables that are hypothesized to be causally related measure the same construct. This type of collinearity is assessed with VIF values, where the values of VIF 3.3 or higher, indicate a potential collinearity (Diamantopoulos \& Siguaw, 2006). Table 6 shows the results of VIF values.

Table 6

Results of Lateral Collinearity Assessment

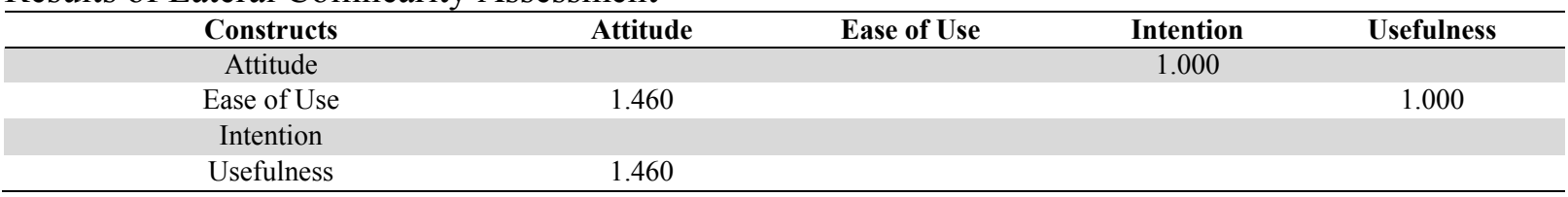

As presented in Table 6 the inner VIF values of the independent variables (Ease of use and Usefulness) that needs to be examined for multicollinearity are less than 5 and 3.3, indicating lateral multicollinearity is not a concern in this study Hair Jr et al. (2014).

\subsection{Hypothesis Testing}

The hypothesis developed for this study were tested by running a bootstrapping procedure with a resample of 5000, as suggested by Hair Jr et al. (2014). The results of Table 7 depict path coefficients of respective constructs with their level of significance. 
Table 7

Results of Structural Model Analysis (Hypothesis Testing)

\begin{tabular}{ccccccc}
\hline$\#$ & Constructs & B & S.E & t-values & P-Values & Results \\
\hline H1 & Usefulness $\rightarrow$ Attitude & 0.388 & 0.057 & 6.875 & $* * *$ & Supported \\
H2 & Ease of Use $\rightarrow$ Usefulness & 0.561 & 0.045 & 12.447 & $* * *$ & Supported \\
H3 & Ease of Use $\rightarrow$ Attitude & 0.188 & 0.066 & 2.851 & $* * *$ & Supported \\
H4 & Attitude $\rightarrow$ Intention & 0.673 & 0.038 & 17.557 & $* * *$ & Supported \\
\hline
\end{tabular}

Note: Significance level where, ${ }^{*} p<0.05,{ }^{* *} p<0.01, * * * p<0.001$.

The results reveal that all four hypotheses had significance relationship with their respective endogenous variables. Table 7 depicts that the relationship between usefulness to attitude is supported by $\mathrm{H} 1$ : $(\beta=0.388, p<0.001)$. Next, the relationship between perceived ease of use to usefulness is supported by $\mathrm{H} 2$ : $(\beta=0.561, \mathrm{p}<0.001)$. H3 showed that perceived ease of use is positively related with attitude by $(\beta=0.188, p<0.001)$. Finally, the results of $\mathrm{H} 5$, where the relationship between attitude to intention is supported by $(\beta=0.673, p<0.001)$.

\subsection{Evaluating Effect Size}

The $R^{2}$ for attitude, perceived usefulness and intention to adopt internet banking were $0.268,0.315$ and 0.453, respectively which are acceptable based on the cut-off suggested by Cohen (1988). Researchers also assessed the effect size of $\left(f^{2}\right)$. As suggested by Cohen (1988) P value can show the effect exists however it does not reveal the size of the effect. In Table 8 the effect of the size of $\left(f^{2}\right)$ can be seen where hypothesis $\mathrm{H} 2$ and $\mathrm{H} 4$ depicted large effect size, whereas $\mathrm{H} 1$ has small effect size and $\mathrm{H} 3$ presented medium effect size as suggested by Cohen (1988). Further to this, researchers also assessed predictive relevance of the model by using the blindfolding procedure. Blindfolding procedure should only be applied to endogenous constructs that have a reflective measurement (Hair Jr et al., 2016). If the $Q^{2}$ values are greater than 0 it shows that the model had predictive relevance for a certain endogenous construct (Cohen, 1988; Hair Jr et al., 2016). Table 8 shows that the value of $Q^{2}$ is greater than 0 that depicts the proposed model had significant predictive relevance.

Table 8

Evaluating Effect Size

\begin{tabular}{cccccc}
\hline Path & Constructs & $R^{2}$ & $Q^{2}$ & $f^{2}$ & Decision \\
\hline & Attitude & 0.268 & 0.191 & & \\
& Intention & 0.453 & 0.260 & & \\
H1 & Perceived Usefulness & 0.315 & 0.216 & & Small \\
H2 & PU $\rightarrow$ ATT & & & 0.141 & Large \\
H3 & PEOU $\rightarrow$ PU & & & 0.460 & 0.033 \\
H4 & PEOU $\rightarrow$ ATT & & & 0.830 & Medium \\
\hline
\end{tabular}

Note: $f^{2}: 0.02$, small; 0.15 , medium; 0.35 , large

\subsection{Importance performance matrix analysis (IPMA)}

A post-hoc importance performance matrix analysis (IPMA) was performed by using intention to adopt internet banking as target construct. The IPMA builds on the PLS estimates of the structural equation model relationship and includes an additional dimension to the analysis of that latent constructs (Hair Jr et al., 2016). The importance scores were carried from the total effects of outcome variable in structural equation model. While performance score or index were derived by rescaling the latent variables score ranges from 0 for the lowest to 100 for the highest (Hair Jr et al., 2016). Table 9 presents the total effects (importance) and index values (performance) used for the importance performance matrix analysis. 
Table 9

Index Values and Total Effects

\begin{tabular}{ccc}
\hline Latent Variables & $\begin{array}{c}\text { Total effect of the latent variable } \\
\text { Intention to adopt Internet Banking } \\
\text { (Importance) }\end{array}$ & $\begin{array}{c}\text { Index values } \\
\text { (Performance) }\end{array}$ \\
\hline Attitude & 0.689 & 67.74 \\
Ease of Use & 0.276 & 63.485 \\
Usefulness & 0.261 & 60.401 \\
\hline
\end{tabular}

Table 9 shows the index values and total effect scores. It can be seen that attitude is the most important factor in order to determine the intention to adopt internet banking due to higher importance values compared to other latent variables. Ease of use is at intermediate level, while perceived usefulness has the lowest importance level after perceived ease of use. The level of importance and performance can be seen in Fig. 3.

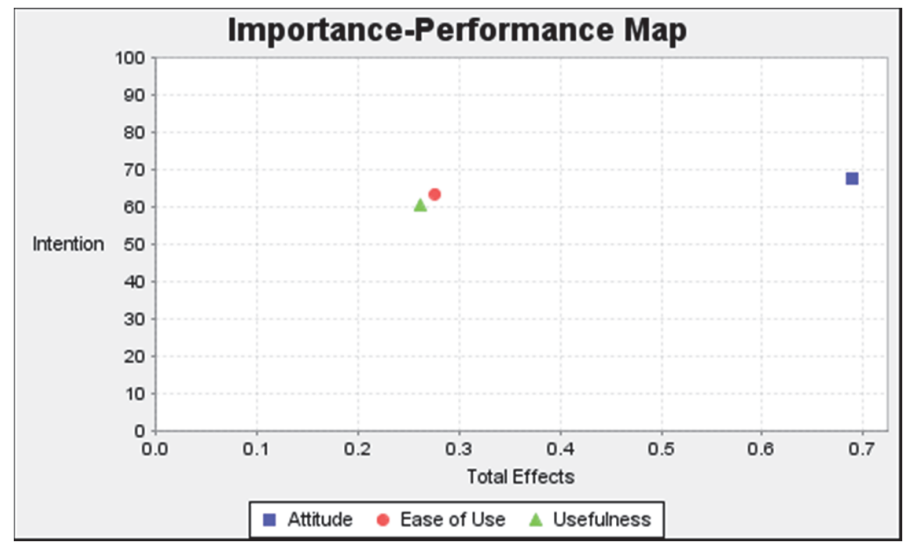

Fig. 3. Importance performance matrix analyses (IPMA)

Importance performance matrix map shows that, attitude has the highest importance level to influence on customers intentions to adopt internet banking. With respect to predecessor of attitude, the constructs perceived ease of use depicted intermediate importance while perceived usefulness showed the lowest importance. To sum up, for managerial activities to achieve customer intention towards adoption of internet banking we should focus on improving the performance of attitude and perceived ease of use.

\section{Discussion and Conclusion}

Drawing upon the technology acceptance factors, this paper has investigated the interrelationship among proposed variables and examined their effects on customer's intentions to use the internet banking. Internet banking is becoming prevalent (Jayawardhena \& Foley, 2000). Improvements in service can only be achieved when it is measured in its first place (Rahi, 2015). Furst et al. (2002) stated that the profitability of the banks by using internet banking was higher than nonusers of internet banking. Furthermore, internet banking is creating new marketing opportunities and improving customer loyalty (Rahi, 2016). In Pakistani banking sector there is a great need to identify the factors that affect adoption of internet banking (Rahi, 2015). The present model provides core factors of technology acceptance that would helpful for new internet banking users. Customers intentions of internet banking was measured with perceived usefulness, perceived ease of use and attitude and findings also supported with previous studies (Al-Bakri \& Katsioloudes, 2015; Bashir \& Madhavaiah, 2015; Kesharwani \& Singh Bisht, 2012; Kumar Sharma \& Madhumohan Govindaluri, 2014; Marakarkandy et al., 2017; Shanmugam et al., 2015). 


\section{Research Contribution}

This study has contributed significantly to research on consumer behavioral intention to adopt internet technology. The contribution of this study is in threefold; theoretical, methodological, and managerial contribution, which are discussed below.

\subsection{Theoretical contribution}

In theory perspective, this study suggests a new direction for academic and researcher by presenting the technology acceptance model factors. It is worthy to note that in measuring adoption behaviors of internet banking users, the proposed technology acceptance model is compatible. The findings of this study suggest that perceived ease of use was the most influential factor after attitude in prediction of customer's intentions. Furthermore, the proposed model makes important contribution to the emerging literature on e-commerce especially in internet banking context.

\subsection{Managerial Implication}

The results of this study revealed that the willingness to adopt internet banking will increase if customers believe that perceived ease of use and perceived usefulness are correctly managed. Perceived ease of use plays a major role on usefulness of internet banking websites. Therefore, banks can focus on website development process and how they can bring easiness in use of internet banking websites. Furthermore, in importance performance matrix analysis attitude has seen the most important factor. Thus, banks can focus on cultivation of positive attitudinal beliefs about internet banking among prospect customers.

\subsection{Methodological Contribution}

This study used structural equation modelling (SEM) approach, respectively, to validate the measurements and test the causal relationships and empirically examined the determinants of customer intention to adopt internet banking. Furthermore, this study collects the actual internet banking customer's responses from one of commercial bank in Lahore city of Pakistan.

\subsection{Limitations and directions for Future Research}

Future research can apply this model in other developing countries to contrast and compare the factors that affect the internet banking adoption. Second, the variables selected in this study may not include all the variables that affect internet banking adoption. Using other variables derived from technology acceptance theory or theory of planned behaviors researchers can observe the behavioral intention of internet banking users. This study is cross-sectional in its nature and measures the internet banking user's behavior at one point in time that may be less significant as compare to longitudinal study.

\section{References}

AbuShanab, E., Pearson, J. M., \& Setterstrom, A. J. (2010). Internet banking and customers' acceptance in Jordan: the unified model's perspective. Communications of the Association for Information Systems, 26(1), 23.

Ajzen, I., \& Fishbein, M. (1980). Understanding attitudes and predicting social behaviour.

Al-Ajam, A. S., \& Md Nor, K. (2015). Challenges of adoption of internet banking service in Yemen. International Journal of Bank Marketing, 33(2), 178-194.

Al-Bakri, A. A., \& Katsioloudes, M. I. (2015). The factors affecting e-commerce adoption by Jordanian SMEs. Management Research Review, 38(7), 726-749.

Bashir, I., \& Madhavaiah, C. (2015). Consumer attitude and behavioural intention towards Internet banking adoption in India. Journal of Indian Business Research, 7(1), 67-102.

Becker, S., Bryman, A., \& Ferguson, H. (2012). Understanding research for social policy and social work: themes, methods and approaches: Policy Press. 
Chin, W. W. (1998). Commentary: Issues and opinion on structural equation modeling: JSTOR.

Cohen, J. (1988). Statistical power analysis for the behavioural sciences. Hillside. NJ: Lawrence Earlbaum Associates.

Compeau, D., Higgins, C. A., \& Huff, S. (1999). Social cognitive theory and individual reactions to computing technology: A longitudinal study. MIS quarterly, 145-158.

Comrey, A., \& Lee, H. (1992). Afirst course infactor analysis. Hillsdale, NJ: Erlbaum.

Davis, F. D. (1989). Perceived usefulness, perceived ease of use, and user acceptance of information technology. MIS quarterly, 319-340.

Diamantopoulos, A., \& Siguaw, J. A. (2006). Formative versus reflective indicators in organizational measure development: A comparison and empirical illustration. British Journal of Management, 17(4), 263-282.

F. Hair Jr, J., Sarstedt, M., Hopkins, L., \& G. Kuppelwieser, V. (2014). Partial least squares structural equation modeling (PLS-SEM) An emerging tool in business research. European Business Review, 26(2), 106-121.

Fornell, C., \& Larcker, D. F. (1981). Structural equation models with unobservable variables and measurement error: Algebra and statistics. Journal of Marketing Research, 382-388.

Furst, K., Lang, W. W., \& Nolle, D. E. (2002). Internet banking. Journal of Financial Services Research, 22(1-2), 95-117.

Gold, A. H., \& Arvind Malhotra, A. H. S. (2001). Knowledge management: An organizational capabilities perspective. Journal of Management Information Systems, 18(1), 185-214.

Hair, J. F. (2003). Essentials of Business Research Methods: Wiley.

Hair, J. F., Black, W. C., Babin, B. J., Anderson, R. E. \& Tatham, R. L. . (2010). Multivariate Data Analysis 7.

Hair Jr, J. F., Hult, G. T. M., Ringle, C., \& Sarstedt, M. (2016). A primer on partial least squares structural equation modeling (PLS-SEM): Sage Publications.

Han, S.-L., \& Baek, S. (2004). Antecedents and consequences of service quality in online banking: An application of the SERVQUAL instrument. ACR North American Advances, 31, 208-214.

Han, S. (2003). Individual adoption of information systems in organizations: A literature review of technology acceptance model. Turku Centre for Computer Science (TUCS).

Henseler, J., Ringle, C. M., \& Sarstedt, M. (2015). A new criterion for assessing discriminant validity in variance-based structural equation modeling. Academy of Marketing Science. Journal, 43(1), 115.

Henseler, J., Ringle, C. M., \& Sinkovics, R. R. (2009). The use of partial least squares path modeling in international marketing. Advances in International Marketing, 20(1), 277-319.

Jayawardhena, C., \& Foley, P. (2000). Changes in the banking sector-the case of Internet banking in the UK. Internet Research, 10(1), 19-31.

Kesharwani, A., \& Singh Bisht, S. (2012). The impact of trust and perceived risk on internet banking adoption in India: An extension of technology acceptance model. International Journal of Bank Marketing, 30(4), 303-322.

Kline, R. (2011). Principles and Practice of Structural Equation Modeling, 3rd edn Guilford Press. New York.

Kock, N., \& Lynn, G. (2012). Lateral collinearity and misleading results in variance-based SEM: An illustration and recommendations.

Kumar Sharma, S., \& Madhumohan Govindaluri, S. (2014). Internet banking adoption in India: structural equation modeling approach. Journal of Indian Business Research, 6(2), 155-169.

Lee, M.-C. (2009). Factors influencing the adoption of internet banking: An integration of TAM and TPB with perceived risk and perceived benefit. Electronic Commerce Research and Applications, 8(3), 130141.

Marakarkandy, B., Yajnik, N., \& Dasgupta, C. (2017). Enabling internet banking adoption: An empirical examination with an augmented technology acceptance model (TAM). Journal of Enterprise Information Management, 30(2), 263-294.

Martins, C., Oliveira, T., \& Popovič, A. (2014). Understanding the Internet banking adoption: A unified theory of acceptance and use of technology and perceived risk application. International Journal of Information Management, 34(1), 1-13. 
Ngah, A. H., Zainuddin, Y., \& Thurasamy, R. (2015). Barriers and enablers in adopting of Halal warehousing. Journal of Islamic Marketing, 6(3), 354-376.

o'Reilly, P., \& Finnegan, P. (2003). Internet banking systems: An exploration of contemporary issues. Journal of systems and information technology, 7(1/2), 93-110.

Rahi, S. (2015). Moderating role of brand image with relation to internet banking and customer loyalty: A case of branchless banking. The Journal of Internet Banking and Commerce, 20(3).

Rahi, S. (2016a). Impact of customer perceived value and customer's perception of public relation on customer loyalty with moderating role of brand image. Journal of Internet Banking and Commerce, 21(2).

Rahi, S. (2016b). Impact of customer value, public relations perception and brand image on customer loyalty in services sector of Pakistan. Arabian Journal of Bussiness Management Review, S, 2, 2.

Rahi, S., \& Ghani, M. (2016a). Internet banking, customer perceived value and loyalty: The role of switching costs. Journal of Accounting and Marketing, 5(2), 188.

Rahi, S., \& Ghani, M. A. (2016b). Customers' perception of public relation in e-commerce and its impact on e-loyalty with brand image and switching cost. Journal of Internet Banking and Commerce, 21(3).

Rahi, S. (2017). Research design and methods: A systematic review of research paradigms, sampling issues and instruments development. International Journal of Economics \& Management Sciences, 6(2).

Rahi, S., Yasin, N. M., \& Alnaser, F. M. (2017). Measuring the role of website design, assurance, customer service and brand image towards customer loyalty and intention to adopt interent banking. The Journal of Internet Banking and Commerce, 22(S8).

Ringle, C. M., Wende, S., \& Becker, J.-M. (2015). SmartPLS 3. Boenningstedt: SmartPLS GmbH.

Shanmugam, M., Wang, Y.-Y., Bugshan, H., \& Hajli, N. (2015). Understanding customer perceptions of internet banking: the case of the UK. Journal of Enterprise Information Management, 28(5), 622-636.

Suleiman Awwad, M., \& Mohammad Agti, D. A. (2011). The impact of internal marketing on commercial banks' market orientation. International Journal of Bank Marketing, 29(4), 308-332.

Venkatesh, V., \& Davis, F. D. (2000). A theoretical extension of the technology acceptance model: Four longitudinal field studies. Management science, 46(2), 186-204.

Venkatesh, V., Morris, M. G., Davis, G. B., \& Davis, F. D. (2003). User acceptance of information technology: Toward a unified view. MIS Quarterly, 27(3), 425-478.

Wang, Y.-S., Wang, Y.-M., Lin, H.-H., \& Tang, T.-I. (2003). Determinants of user acceptance of Internet banking: an empirical study. International Journal of Service Industry Management, 14(5), 501-519.

Wixom, B. H., \& Todd, P. A. (2005). A theoretical integration of user satisfaction and technology acceptance. Information systems research, 16(1), 85-102.

Wu, S.-I. (2006). A comparison of the behavior of different customer clusters towards Internet bookstores. Information \& Management, 43(8), 986-1001.

Yee-Loong Chong, A., Ooi, K.-B., Lin, B., \& Tan, B.-I. (2010). Online banking adoption: an empirical analysis. International Journal of Bank Marketing, 28(4), 267-287.

Zeithaml, V. A., Berry, L. L., \& Parasuraman, A. (1996). The behavioral consequences of service quality. the Journal of Marketing, 60(2), 31-46.

Zhang, X., \& Prybutok, V. R. (2005). A consumer perspective of e-service quality. IEEE transactions on Engineering Management, 52(4), 461-477.

Zhuang, Y., \& Lederer, A. L. (2004). The impact of top management commitment, business process redesign, and IT planning on the business-to-consumer e-commerce site. Electronic Commerce Research, 4(4), 315-333.

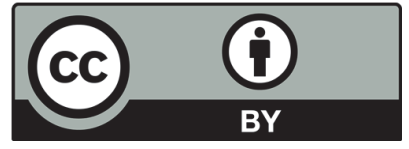

(C) 2017 by the authors; licensee Growing Science, Canada. This is an open access article distributed under the terms and conditions of the Creative Commons Attribution (CC-BY) license (http://creativecommons.org/licenses/by/4.0/). 